\title{
Sheffield medium for cultivation of Haemophilus ducreyi
}

\author{
S HAFIZ,* M G MCENTEGART,* AND G R KINGHORN† \\ From the *Department of Medical Microbiology, University of Sheffield Medical School, and the \\ †Department of Genitourinary Medicine, Royal Hallamshire Hospital, Sheffield
}

SUMMARY Our interest in the role of Haemophilus ducreyi in genital ulceration led us to examine the various media commonly used for the cultivation of the organism. We describe an improved medium for the routine isolation of $H$ ducreyi. In comparative studies using 50 test strains originally isolated in the United Kingdom, Canada, the United States of America, and Kenya, the new medium proved superior to three standard media in requiring a shorter incubation period to first visible growth, giving larger colonies in the same period, and making possible a starch aggregation test which we have found helpful in the presumptive identification of $H d u c r e y i$ from clinical material.

\section{Introduction}

Haemophilus ducreyi is a fastidious organism which was, until recently, considered to be so difficult to grow that the diagnosis of chancroid was commonly based on the microscopical appearance of stained films of ulcer exudate and on the exclusion of all other causes of genital ulceration. ${ }^{1}$ The introduction of improved culture methods for its isolation ${ }^{2-5}$ has helped to make the laboratory identification of $H$ ducreyi reliable, and the diagnosis of chancroid therefore more certain. Nevertheless the media currently used may still pose problems, especially in needing a long incubation time, giving variable colony sizes, and showing diverse microscopical appearances on Gram stained smears prepared from colonies. In this study we compared an improved Sheffield medium with other standard media in cultivating strains of $\boldsymbol{H}$ ducreyi originally isolated from patients attending sexually transmitted disease (STD) clinics.

\section{Materials and methods}

STRAINS OF H DUCREYI

We studied 50 strains of $H$ ducreyi, 25 from patients attending the department of genitourinary medicine at this hospital, 15 from patients with chancroid in

Address for reprints: Dr S Hafiz, Department of Medical Microbiology, University of Sheffield Medical School, Beech Hill Road, Sheffield S10 2RX

Accepted for publication 9 November 1983
Canada and Kenya (supplied by Dr A Ronald), four from patients with chancroid in Seattle (supplied by Dr H Handsfield), five isolated in Orange County, California (supplied by Dr J R Greenwood), and the NCTC (National Collection of Type Cultures) strain 10945.

\section{MEDIA}

The four media used were: (a) enriched chocolate agar $^{2}$ consisting of GC base (Difco) and distilled water with $1 \%$ haemoglobin and $1 \%$ isovitalex added as supplements; (b) fetal bovine serum agar $^{3}$ consisting of $40 \mathrm{~g}$ of heart infusion agar (Difco) dissolved in $900 \mathrm{ml}$ distilled water and sterilised by autoclaving, to which $100 \mathrm{ml}$ of fetal bovine serum were added as supplement; (c) modified haemin medium $^{5}$ consisting of GC base (Difco), proteose peptone, gelatin, defined supplement, and $250 \mathrm{mg} / 1$ of equine haemin type III (Sigma); and (d) Sheffield medium, which was an improvement of the modified haemin medium and was prepared as follows:

\section{Part I}

Thirty $\mathrm{g}$ proteose peptone no 3 (Difco), $1 \mathrm{~g}$ rice starch, $4 \mathrm{~g}$ potassium phosphate (dibasic), $1 \mathrm{~g}$ potassium phosphate (monobasic), $5 \mathrm{~g}$ sodium chloride, $4 \mathrm{~g}$ gelatin, and $10 \mathrm{~g}$ agar were soaked in $1000 \mathrm{ml}$ distilled water for 30 minutes, mixed, sterilised by autoclaving at $67 \mathrm{kPa}\left(10 \mathrm{lbs} / \mathrm{in}^{2}\right)$ pressure and $115^{\circ} \mathrm{C}$ for 15 minutes, and cooled to $56^{\circ} \mathrm{C}$ in a water bath. 


\section{Part II (Stable defined supplement)}

One $\mathrm{g}$ gelatin and $1 \mathrm{~g}$ glutamine were dissolved in $90 \mathrm{ml}$ distilled water at $100^{\circ} \mathrm{C}, 40 \mathrm{~g}$ glucose was added, and the gelatin solution was cooled to about $10^{\circ} \mathrm{C}$. A solution of $0.05 \mathrm{~g}$ ferric nitrate was dissolved without heating in $10 \mathrm{ml}$ distilled water, mixed with the gelatin solution by stirring vigorously, distributed in $10 \mathrm{ml}$ amounts, sterilised by autoclaving at $67 \mathrm{kPa}\left(10 \mathrm{lbs} / \mathrm{in}^{2}\right.$ pressure and $115^{\circ} \mathrm{C}$ for 15 minutes, and stored in the dark until required.

\section{Part III}

One $g$ of equine haemin type III (Sigma) was dissolved in $25 \mathrm{ml}$ of $0.2 \mathrm{ml}$ potassium hydroxide in $47 \cdot 5 \%$ ethanol, and $75 \mathrm{ml}$ distilled water was added. The solution was sterilised by filtration and distributed in $20 \mathrm{ml}$ amounts.

\section{Sheffield medium}

The final medium was made by mixing one litre Part I, $10 \mathrm{ml} \mathrm{Part} \mathrm{II,} \mathrm{and} 20 \mathrm{ml}$ Part III and adding $5 \%$ horse defibrinated blood (Oxoid Code SR50) to give better growth. The $\mathrm{pH}$ of the medium should be $7 \cdot 0-7 \cdot 2$, and if it was lower than $7 \cdot 0$ it was adjusted by adding N/10 (one tenth normal) sodium hydroxide.

\section{INOCULA}

All identified strains of $H$ ducreyi were cultured on Hammond's medium ${ }^{2}$ and on modified haemin ${ }^{5}$ medium and then incubated at $33-34^{\circ} \mathrm{C}$ in $5 \%$ carbon dioxide for 96 hours. Growth from each of these cultures was scraped off, suspended in phosphate buffered saline (PBS), mixed on a Vortex mixer for five minutes, and left for $\mathbf{1 0}$ minutes for the larger lumps to settle. A standard loopful of each of these suspensions was inoculated on to seven replicates of the four media tested. Inoculated plates were incubated under the optimum conditions described below and results were read every 24 hours for seven days, the plates being examined for typical type, size, coherence, and starch aggregation. ${ }^{6}$ Films were also prepared by Gram's staining and examined for typical morphology. Preliminary experiments using NCTC strain 10945 and several local isolates on all four media had shown that inoculated plates incubated at $37^{\circ} \mathrm{C}$ gave less growth than at $33-34^{\circ} \mathrm{C}$, or none.

\section{Results}

On all four media, the strains produced characteristic $H$ ducreyi colonies which were difficult to emulsify and could be pushed intact across the surface of the plate.

The table shows that colonies were largest on the new medium, which also gave visible growth after incubation for $\mathbf{4 8}$ hours with $\mathbf{4 0}$ of the $\mathbf{5 0}$ strains tested, and with all 50 strains after incubation for four days. In this respect the new medium was superior to the other three media tested. Gram stained smears of colonies from the new medium more often showed the typical "rail road tracks" appearance, as shown in the figure.

Starch aggregation ${ }^{6}$ was seen on modified haemin medium after four days, but after only two days with the new medium. It was not seen on either Hammond's (enriched chocolate agar) ${ }^{2}$ or Sottnek's (fetal bovine serum agar) ${ }^{3}$ medium.

\section{Discussion}

With the introduction of reliable culture methods our concept of $\boldsymbol{H}$ ducreyi has changed from that of a rare organism which was extremely difficult to isolate to an organism which, with care, can be grown and identified in a routine laboratory. We found that the

TABLE $A$ comparative growth of 50 strains of $H$ ducreyi inoculated on four media

\begin{tabular}{|c|c|c|c|c|c|c|c|c|c|c|}
\hline \multirow[b]{2}{*}{ Medium } & \multicolumn{7}{|c|}{$\begin{array}{l}\text { No of strains showing visible growth } \\
\text { on days: }\end{array}$} & \multirow{2}{*}{$\begin{array}{l}\text { Size and colour } \\
\text { of colonies }\end{array}$} & \multirow{2}{*}{$\begin{array}{l}\text { Appearance on } \\
\text { Gram's staining }\end{array}$} & \multirow{2}{*}{$\begin{array}{l}\text { Starch } \\
\text { aggregation }\end{array}$} \\
\hline & 1 & 2 & 3 & 4 & 5 & 6 & 7 & & & \\
\hline $\begin{array}{l}\text { Enriched } \\
\text { chocolate agar }\end{array}$ & & 25 & 35 & 45 & 50 & 50 & 50 & $\begin{array}{l}\text { Small } \\
\text { non-mucoid } \\
\text { yellow-grey } \\
\text { translucent }\end{array}$ & \multirow{3}{*}{$\begin{array}{l}\text { Gram negative } \\
\text { rods in clumps } \\
\text { or short chains } \\
\text { on occasional } \\
\text { rail road tracks }\end{array}$} & Negative \\
\hline $\begin{array}{l}\text { Fetal bovine } \\
\text { serum agar }\end{array}$ & & 22 & 31 & 42 & 48 & 48 & 48 & $\begin{array}{l}\text { Slightly } \\
\text { mottled and } \\
\text { irridescent }\end{array}$ & & Negative \\
\hline Modified haemin & & 26 & 35 & 48 & 50 & 50 & 50 & $\begin{array}{l}\text { Small to large } \\
\text { non-mucoid } \\
\text { greenish brown }\end{array}$ & & $\begin{array}{l}\text { Positive after } \\
4 \text { days }\end{array}$ \\
\hline Sheffield & 2 & 40 & 47 & 50 & 50 & 50 & 50 & $\begin{array}{l}\text { Large } \\
\text { non-mucoid } \\
\text { greenish brown }\end{array}$ & $\begin{array}{l}\text { Rail road tracks } \\
\text { common }\end{array}$ & $\begin{array}{l}\text { Positive after } \\
2 \text { days }\end{array}$ \\
\hline
\end{tabular}




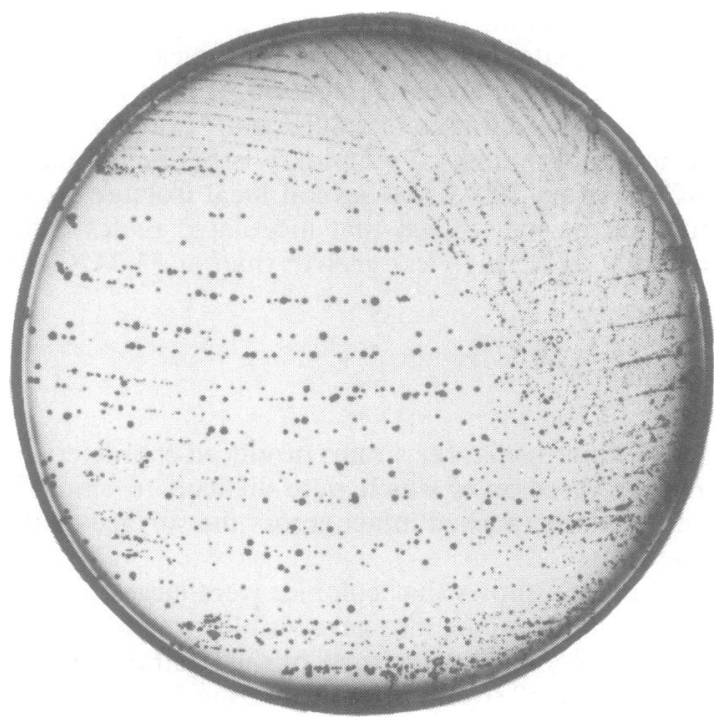

FIGURE Typical rail road tracks appearance of $H$ ducreyi colony growing on new Sheffield medium.

lower incubation temperature of $33-34^{\circ} \mathrm{C}$ was necessary for optimum growth of $\boldsymbol{H}$ ducreyi.

In this study the improved Sheffield medium proved superior to the others tested in terms of time to first visible growth, while maintaining the characteristic colonial morphology of $H$ ducreyi. As well as giving larger colonial size, it enabled starch aggregation to be used as an additional means of identifying an otherwise inert organism. The starch aggregation reaction, which facilitates recognition of even single colonies of $\boldsymbol{H}$ ducrey in heavily contaminated plates, is negative in all media containing serum, possibly because of starch binding. ${ }^{6}$ The addition of vancomycin $(3 \mathrm{mg} / \mathrm{l})$ to the medium inhibits the growth of Gram positive organisms from the polymicrobial flora of genital ulcers, and is advocated for the primary isolation of $H$ ducreyi from clinical specimens. Use of this medium in STD clinics may increase the number of confirmed diagnoses of chancroid.

\section{References}

1. McEntegart MG, Hafiz S, Kinghorn GR. Haemophilus ducrey infections-time for reappraisal. Journal of Hygiene (Cambridge), 1982;89:467-78.

2. Hammond GW Lian CJ, Wilt JC, Ronald AR, Comparison of specimen collection and laboratory techniques for isolation of Haemophilus ducreyi. J Clin Microbiol 1978; 7:39-43.

3. Sottnek FO, Biddle JW, Kraus SJ, Weaver RE, Stewart JA. Isolation and identification of Haemophilus ducreyi in a clinical study. J Clin. Microbiol 1980;12:170-4.

4. Hafiz S, Kinghorn GR, McEntegart MG. Chancroid in Sheffield. Br J Vener Dis 1981;57:382-6.

5. Kinghorn GR, Hafiz S, McEntegart MG. Modified haemin containing medium for isolation of Haemophilus ducreyi. Lancet 1982; i: 383-4.

6. Hafiz S, Kinghorn GR, McEntegart MG. Starch aggregation as a presumptive test for Haemophilus ducreyi. Lancet 1982; ii: 872. 
We are also currently investigating the incidence of anaerobic vaginosis in a local general practice using the method outlined above, and have found that specimens which have been air dried and stored for up to 14 days before Gram staining show no deterioration.

We suggest that doctors concerned with the management of vaginal discharge who do not have immediate access to clinic or laboratory facilities might find this a cost effective alternative to the high vaginal swab.

$$
\begin{aligned}
& \text { Yours faithfully, } \\
& \text { A Blackwell } \\
& \text { D Barlow }
\end{aligned}
$$

Department of Genitourinary Medicine, St Thomas' Hospital,

London SE1 7EH

\section{References}

1. Amsel R, Totten PA, Spiegel CA, Chen KCS, Eschenbach D, Holmes KK. Nonspecific vaginitis. Diagnostic criteria and microbial and epidemiologic associations. Am J Med 1983; 74: 14-22.

2. Blackwell AL, Fox AR, Phillips I, Barlow D. Anaerobic vaginosis (non-specific vaginitis): clinical, microbiological and therapeutic findings. Lancet 1983; ii: 1379-82.

3. Blackwell AL, Barlow $\mathrm{D}$. Vaginal discharge. Br Med J 1984; 288: 69.

4. Dunkelberg WE. Diagnosis of Haemophilis vaginalis vaginitis by Gram-stained smears. Am J Obstet Gynecol 1965;91:998-1000.

\section{Correction}

There was an error in the paper by S Hafiz et al on Sheffield medium for cultivation of Haemophilus ducreyi (1984;60:196-8). The last three sentences of the second paragraph in the Results section should have read: "In this respect the new medium was superior to the other three media tested. This is shown in the figure, which illustrates the colonial appearance. Gram stained smears of colonies from the new medium more often showed the typical "rail road tracks" appearance." The legend for the figure should have read: "Colonial appearance on Sheffield medium."
TO THE EDITOR, British Journal of Venereal Diseases

Treatment of anogenital warts with trichloroacetic acid and podophyllin

Sir,

I read with interest the article by Gabriel $e t$ $a l^{1}$ on the treatment of anogenital warts comparing the effect of trichloroacetic acid and podophyllin with podophyllin alone. In their study they report no appreciable difference except that fewer applications of trichloroacetic acid and podophyllin were necessary than with podophyllin alone.

I report on two patients (one Turkish and another Somalian) whose warts resolved completely after three applications of trichloroacetic acid $(100 \%)$ and podophyllin $(25 \%)$ at weekly intervals. The two preparations were not mixed together and were applied from different bottles (first trichloroacetic acid and then podophyllin).

What prompted me to use this combination was that both patients were resistant to treatment first with podophyllin alone for two months (eight applications) and then with trichloroacetic acid alone for another month (four applications).

Although I have treated only resistant cases with this combination (with higher concentration of trichloroacetic acid than was used by Gabriel $e t a l$ ), the dramatic improvement, in my opinion, is important. Yours faithfully, Malkit Singh

\section{Notice}

Conference of the African Union Against Venereal Diseases and Treponematoses

The African Union Against Venereal Diseases and Treponematoses will be holding a conference on 1-5 April 1985 in Libreville, Gabon. There will be a workshop on chlamydial infections on 1 and 2 April and a conference on infertility and STD in Africa from 3 to 5 April.
Department of Medicine, Division of Dermatology, University of Garyounis, PO Box 6674,

Benghazi, Libya

\section{Reference}

1. Gabriel G, Thin RNT. Treatment of anogenital warts. Comparison of trichloracetic acid and podophyllin versus podophyllin alone. Br J Vener Dis 1983;59: 124-6.

TO THE EDITOR, British Journal of Venereal Diseases

\section{Buschke-Loewenstein tumour of the penis}

Sir,

We agree with the letter from Ingber et al (Br J Vener Dis 1984;60:205) stating that laser treatment would be the treatment of choice if it were available. Only one laser unit was available elsewhere, and the surgeons concerned were not convinced that it was suitable in this particular case.

Penile lesions are more difficult to operate on than scrotal lesions due to vascularity and the effect of urine.

Our patient's subtotal amputation was unavoidable because of his presentation, and the massive involvement of the shaft of the penis.

\section{Yours faithfully,} Janina M Harvey $G$ Watson

Falkirk and District Royal Infirmary, Falkirk 